\title{
Rethinking the past to manage the future: Participating in complex contexts informed by biblical perspectives
}

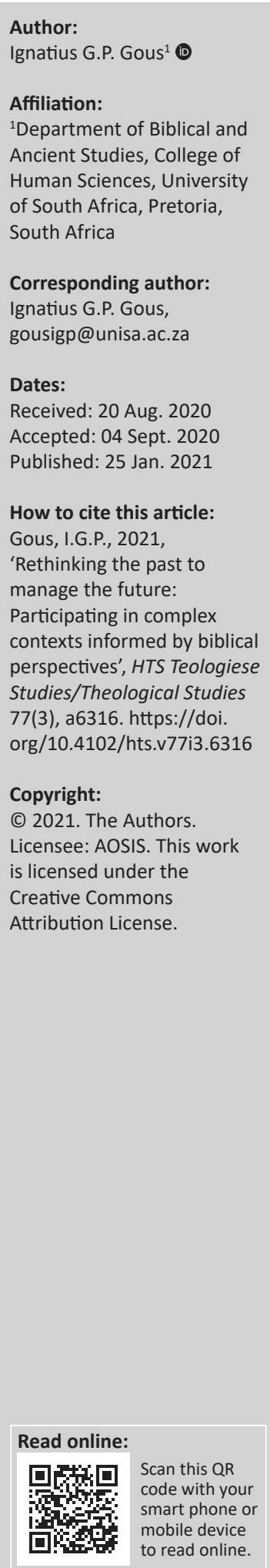

Change is the new normal, but so it has been for ages. Experience to navigate change is something you get just after you needed it, unless you tap into age-old experience. The Fourth Industrial Revolution (4IR) is bringing about wide-ranging changes. With people having to adjust, the question is whether Christianity, with its roots in preindustrial times, may support people to navigate these changes. This conceptual article focusses on the relationships amongst constructs, exploring logical arguments about how these constructs are associated. The 4IR is briefly described from differing vantage points, as to whether it is a valid description thereof. Whether a revolution or evolution, it is a complex system, and therefore the theory of complex systems is used, with the conclusion that one may merely participate in such systems. Being novel situations, one needs to participate creatively, based on a cognitive understanding of creativity. Creative solutions do not materialise out of thin air but are the novel use of existing knowledge structures. Christian traditions include institutional memories of how people managed situations of radical change, as reflected in Genesis 1 and Lamentations 4. These passages provide building blocks that may be used in creative coping strategies during times of change. Both passages suggest the strategy to juxtapose order and chaos, and borrowing from that, a 'Grip-Grapple-Grow' scaffolding system is suggested. To test the usability thereof, the issue of face masks during the Coronavirus Disease 2019 pandemic was touched upon, to evaluate how the interplay amongst 4IR, disruption, (Christian) beliefs and technological advancement may play out.

Contribution: The Fourth Industrial Revolution is speeding up the pace of change, with people having to adapt. This article explores processes of change management, juxtaposing the theory of complex systems, the cognitive science understanding of creativity and institutional memories afforded by some Christian traditions reflecting on how people managed order and chaos.

Keywords: Complexity theory; Fourth Industrial Revolution; 4IR; Creativity; Genesis 1; Lamentations 4; COVID-19 pandemic; Face masks.

\section{Introduction: Change as the new, and recurring, normal}

It seems that change is the new normal. The future is not what it used to be, and probably never will be. On the other hand, change has always been a feature of the human condition. Natural disasters influenced livelihood. Wars disrupted societies. New knowledge and new technologies changed the way people thought and lived. It is therefore not entirely the 'new' normal. It is only new for people who are expecting stability and predictability, but who are experiencing changing times without the luxury of hindsight.

Managing change resulting from any of a plethora of events is therefore part of the human condition. It always has been, and always will be. The only difference might be one of scale, namely how impactful change is in a certain time and age and how comprehensive the management of change needs to be.

The current era is a time of sweeping and wide-ranging change brought about by rapid technological developments and impacting substantially on the human condition. For this reason, it has even been assigned the name of the Fourth Industrial Revolution (4IR), and people from all vantage points are contemplating the impact thereof on human lives and societies and how to manage it. 
This volume has a similar aim, but coming from a particular vantage point, namely, that of the Christian Church and tradition, which makes out a sizable sector of the society. The current wave of change is impacting on every aspect of the human condition and all societal structures, also impacting religious sectors of societies. For this reason, it is valid to question how Christianity should manage the changes brought about by current events. The Christian community, however, is currently in an identity crisis and pondering its continued relevance now and for the next millennia. Is it then possible for Christianity to act as a change agent in the 4IR world?

This article is therefore a conceptual paper exploring possible contributions from a Christian perspective on how to manage change brought about by 4IR. A conceptual paper, according to Gilson and Goldberg (2015:127-128), does not have data because it addresses questions that cannot be discussed simply by getting more factual information. Instead of testing them empirically, it rather focuses on relationships amongst constructs, exploring logical arguments about how these constructs are associated. According to Cropanzano (2009:1306), such papers 'seek to bridge existing theories in interesting ways, link work across disciplines, provide multilevel insights, and broaden the scope of our thinking'.

\section{Issue addressed, hypothesis, goal and theoretical bases}

The problem to be addressed is whether a part of society, which is seen by some as dated or even outdated (Oliver 2019), will be able to be involved as a change agent and contribute to and participate in a trailblazing and groundbreaking movement.

The hypothesis is that contemporary and creative attempts to manage change benefit from and build upon previous experiences, and therefore collective Christian traditions and institutional memories about managing change are useful and generative for handling contemporary challenges and managing present-day change.

The goal of the study therefore is to discuss reflections about major changes in an erstwhile community and their faith-based reflections on it to formulate principles for current approaches whereupon programmes aimed at managing the changes brought about by 4 IR can be formulated.

To do this, 4IR is to be described as a complex system, which people cannot direct, but merely participate in. Insights from the sciences of complexity will be used for this aspect.

A second aspect is to discuss creativity as a way to manage novel challenges. Per definition, creativity follows upon the juxtaposition of two or more seemingly unrelated issues as is done here with 4IR and religion, and where creative solutions are always built upon available knowledge and insights. The mere fact that this volume juxtaposes seemingly irreconcilable issues such as 4IR and religion invites creativity.
Insights from the cognitive scientific study of creativity will be used for this aspect.

The 'institutional memory' of Christianity will be interrogated by focusing on events referred to by the Old Testament and how these events and the changes they introduced were interpreted. Although these events preceded Christianity, the Old Testament is appropriated by Christian tradition and plays a role in formulating insights for Christian believers.

Based on these insights, a programme of action, intervention and participation is formulated, this time reflecting on a specific event, namely the fall of Jerusalem in $586 \mathrm{BCE}$, and the reflection on that as seen in Lamentations 4 in the Old Testament. Juxtaposing order and chaos, a reaction in iterative phases which can be named 'Grip, Grapple and Grow' is proposed.

\section{The Fourth Industrial Revolution as a complex system}

All people try to make sense of their lived realities and experiences by looking back and trying to explain and categorise events. Sometimes this is done to come to terms with traumatic experiences. Sometimes it is done to relive pleasant and positive events. Most of the time, it is done to help them cope with their current situation with an eye on planning for the future, especially in times of disruption of systems and societies.

In 2015, Klaus Schwab wrote an article in which he described the current developments and innovations taking place in our world as the 'Fourth Industrial Revolution', contemplating 'what it means and how to respond' (Schwab 2015). He elaborated his ideas in a subsequent book (Schwab 2016).

His depiction of events follows on three previous so-called Industrial Revolutions (Schwab 2016:11-12; Xu, David \& Kim 2018:91). The First Industrial Revolution took place at the end of the 18th and beginning of the 19th centuries, usually dated $1765 \mathrm{CE}$ and onwards, and was about mechanising production. The driving force in this era was most notably the steam engine. Whilst Leonardo da Vinci invented many pioneering machines, all of them were hampered in effectiveness because they relied on human power, although augmented. Steam engines changed all of this, and the mechanisation that followed enabled agriculture on a much larger scale, as well as travel and manufacturing. This led to urbanisation and other societal changes.

The Second Industrial Revolution started towards the end of the 19th century, from $1870 \mathrm{CE}$ and onwards, and was about mass production. New sources of energy, such as oil, gas and electricity, became available. This enabled the optimisation of the internal combustion engine, which enabled effective transport by land, sea and air. Added to this is the development of steel and other building materials, as well as new modes of communication. 
The Third Industrial Revolution took place almost a century later, starting from 1969, and was about the automation of production. The development and availability of computers and electronics changed the way communications and the flow of information took place and enabled programmable and high-level automation.

According to Schwab (2015, 2016:12), the 4IR (also called Industry 4.0) has been taking place since 2000 and is ongoing. Some even want to suggest that the Fifth Industrial Revolution started, but it has not found wide acclaim. The computerisation of the Third Industrial Revolution enabled the fusion of technologies that led to the development of cyber-physical systems, in other words a computer-human interface. In addition to this, the Internet of Things controls by means of computers even the most mundane aspects of human life, and the Internet of Systems is where smart technologies are implemented in the workplace and in manufacturing. The impact of $4 \mathrm{IR}$ is much faster and more widespread than the previous industrial revolutions because it impacts across all economies, disciplines and industries.

Since then, Schwab founded the World Economic Forum, and he is currently the CEO of this organisation. Part of their activities is the yearly meeting at Davos, where world leaders gather to discuss matters of economic importance and cooperation in the light of $4 \mathrm{IR}$. For this reason, many articles have been focusing on 4IR, in every country, context and industry. Schwab himself (2016) portrays the technologies developed and used in 4IR as carrying enormous potential and promise but also carrying many risks and peril, creating exponential and massive change in a non-linear way. For this reason, he believes (2016) that decision- making needs to change from being traditional and linear to being strategically concerned with forces of innovation and disruption which are shaping our future.

The promises, according to Schwab and many others, are a better quality of life and raised income levels, impacting business, government and individuals.

On business level, the four main effects will be different customer expectations, better products, more innovation and new ways organisations are structured.

On government level, issues of control, regulation and security come to the fore. Rapid non-linear development makes control and regulation a challenge for systems that work in linear and mechanistic ways. The same holds true for security and conflict, which are becoming hybrid in nature and need to be managed in novel ways.

On a personal level, these new technologies open so many new and enabling ways of living and being, even open new avenues to show compassion and to cooperate. At the same time, however, it also carries within challenges regarding identity and privacy, which need to be considered.
The perils, according to Schwab (2016:37) and others such as Prisecaru (2016:60), are societal concerns because of the possibility of greater inequality as well as labour market disruption.

Greater inequality may result from a gap in wealth between providers of intellectual and physical capital, on the one hand, and people dependent on their labour, on the other hand. The investors, innovators and shareholders will be highly paid, whilst workers will not be. The expectation is that the job market will have a strong demand on the low and high ends, with a stagnation of demand and income levels for the middle class.

Automation is expected to result in disruption of labour markets and in job losses, as robots and artificial intelligence replace human involvement.

The question could and should be asked whether these are true reflections, descriptions and expectations of the times we live in. Reality is so complex, and there is always the danger of a limited take on what is happening or a skewed perspective of reality. For this reason, some insights from the sciences of complexity are offering some valuable light Innes \& Booher 2018; Kauffman 1993; MacIntosh \& Maclean 2015; Northrop 2010; Peat \& Briggs 1999; Wahl 2017, 2019). The sciences of complexity are researching complex systems alike to those described as 4IR. It is, therefore, worthwhile to see how these sciences are handling the description and analysis of complex systems to gauge the validity of the depictions and descriptions of $4 \mathrm{IR}$.

Complexity refers to attempts to understand the emergence of some kind of order in complex adaptive systems (MacIntosh \& MacLean 1999:297, MacIntosh \& MacLean 2001:1343; MacIntosh et al. 2006). Systems consist of networks of elements interacting with each other, and some of these interactions are more impactful and play a larger role in the system. Because of this, the system changes towards a new but unpredictable order. Although unpredictable, the new order is constrained by conditions initially available, which rules they follow and which patterns of interconnection are available (MacIntosh \& MacLean 2015:152). The chaos from which the new order emerges is not total and incoherent disorder, but rather apparent random events, which even though random, an underlying interconnectedness exits between them. According to Peat and Briggs (1999:2), chaos science, which is part of the sciences of complexity, 'focuses on hidden patterns, nuance, the sensitivity of things, and the rules for how the unpredictable leads to the new'.

Complexity thinking describes the dynamics of systems, such as ecological, mechanical, chemical or electric systems, as resulting from four key principles (MacIntosh \& MacLean 2015:152-154).

Firstly, systems are densely interconnected. Parts of the system influence the others, and small events can have large-scale outcomes in unexpected non-linear ways, not to be expected and explained by cause and effect. This is 
sometimes referred to as 'the butterfly effect' where a small event in one location may lead to a major change in another.

Secondly, contrary to expectation, systems often exist in states of non-equilibrium. This is the reason that small changes may have huge effects.

Thirdly, systems stay stable or change in non-linear ways, and the extent thereof is linked to positive (amplifying) or negative (restorative or damping) feedback.

Fourthly, order in a system is the result of a process of self-organisation, which entails repeated application of simple rules.

The dynamics of complex adaptive social systems are furthermore influenced by aspects of reflexivity, voluntary behaviour and participation (MacLean \& MacIntosh 2003:163).

Based on these principles, change may occur either episodically (revolutionary) or perpetually (evolutionary). During episodical or dissipative change, some external trigger or triggers initiate revolution-like distinct phase transitions in systems, transforming from one stable state to a following. On the other hand, systems might be in perpetual fluidity, being 'in a zone on the edge of chaos'. These systems adapt and self-organise repeatedly and gradually in an evolutionary manner to stay compatible with an ever-changing environment (MacIntosh \& MacLean 2015:155)

With these insights in mind, the question is whether the fourth and the previous three industrial revolutions are rightly described as revolutions, or whether they evolved in time. What we also should ask is, whichever of the two it is, or even both, how should we find our way and exist in these times. Can we plan, can we intervene and can we control outcomes and directions?

Starting with the last question, the answer seems to be that we can merely participate, but not control. The fundamental unpredictability excludes prediction and control, leaving only the option of participation in the processes, based on humble, transdisciplinary, careful consideration, whilst all the time being cautious of the effects on ourselves and others of what we do and how we participate. In a complex system with many opportunities and threats for ourselves and others, considered and responsible participation is necessary.

Addressing the question whether the events are rightly depicted as revolutions, some other voices need to be heard.

Tim Unwin, a UNESCO Chairholder in Information and Communication Technologies for Development (ICT4D), believes the ways in which the notion of a 4IR is depicted by mainline publications and proponents are fatally flawed. $\mathrm{He}$ mentions at least five problems in this regard.
The first problem is the assertion that it is technology that is changing the world. Every so-called industrial revolution is accredited to a particular technology: mechanisation and steam, electricity, computers and automation and currently cyber-physical systems. According to him, however, technology does not bring about change. It is people who are changing the world, and more specifically, the interests and objectives of the inventors, designers and owners they are serving.

The second problem is the view of history, especially the question whether societies change in revolutionary or evolutionary ways. He believes that the so-called revolutionary changes that can be described as clear-cut events are the result of developments that evolved over time. All the revolutions of the past 400 years are the result of how markets were created and expanded, and how labour costs were impacted on and reduced by making use of technology. The technologies might be new, but the driving forces and interests behind them are basically the same and have been influencing events over long periods of time.

The third problem is what he sees as an elite view of history. The people who are portrayed as the champions of the revolution are elite business leaders, politicians and academics, mainly from the USA. The poor and the marginalised are being sidelined, as if they do not contribute anything.

The fourth problem links to the third, by exclusively focusing on the male industrialists and innovators of the revolution, ignoring the important contributions of women and the marginalised. This also makes it more difficult to inspire women to become part of the processes.

The fifth problem, according to Unwin, is that $4 \mathrm{IR}$ is a selffulfilling prophecy. He describes Schwab's book and subsequent publications as more of a programme for the future than a historical account of what has happened. He then accuses proponents of $4 \mathrm{IR}$ as being a 'conspiracy to shape the world ever more closely in the imagination of a small, rich, male and powerful élite' (Unwin 2019, in https: / / unwin.wordpress.com/2019/03/09/why-the-notion-of-afourth-industrial-revolution-is-so-problematic/).

This differing account and interpretation of events underscore the difficulty of making sense of complex systems. It also emphasises the importance of how necessary it is to have a multitude of perspectives on a complex system, as to avoid narrow and parochial interpretations. For this reason, a view from a religious point of view may shed valuable collateral light, whilst at the same time knowing that there is no such thing as only one view or only one religion.

Whether current events should be depicted as a revolution or an evolution might be a case of semantics. The main difference is whether what is happening is swift and telling or prolonged and developing. To my mind, revolutions is more clear-cut 
and something that happen to people, whilst during evolutions there is more opportunity for people to participate in the unfolding of events. It also allows for people to occupy different positions whilst being in different stages of development.

Whatever the depiction might be, the reality is that we are in a period of sweeping changes and the forging of new realities. The only option is to choose to participate. If not, the processes are not going to stop, and those who do not participate will be left behind or sidelined.

The bottom line is that all people on earth are being impacted by current changes, whether they are elite or not, powerful, or marginalised. Most people use to a greater or lesser extent the currently available technologies resultant from the technological revolutions, such as mobile phones. Most jobs are changing because of this. All societies are experiencing changes, some for the better and some for the worse. We, therefore, are all participants in these systems, with sometimes more and sometimes less impact and influence on it.

If participation is the only option, then what is left is the decision to choose how to participate. If we cannot cause and control, should one then support what is happening, or sabotage and block it, or try to change the course of what is happening? The only way to decide is to participate based on a broad, interdisciplinary knowledge and understanding of what is going on. The implication is that lifelong learning is crucial to be and stay informed. It is also important to be suitably informed, and because it is such a complex situation it calls for being interdisciplinary informed, focusing not only on technology, but also on the human aspects and the implications for them. In this process we have to take context into account, because we live in different and differing worlds.

One way to describe these kinds of complex situations is using the volatility, uncertainty, complexity and ambiguity (VUCA) acronym. Based on the leadership theories of Warren Bennis and Burt Nanus since 1985 (Bennis \& Nanus 1985), it was used to describe unpredictable and constant change in areas of the worlds of business, industry, leadership, organisations, corporations and in education by describing it in terms of VUCA. The 4IR does not have copyright on disrupting systems. The VUCA call was to avoid outdated and traditional approaches to complex challenges. Resistance to change, inflexible and autocratic leadership styles and groupthink are realities that prevent people and organisations to come to terms with complex situations. Creative and agile processes are necessary, and for that reason Bill George, a senior fellow at Harvard Business School, argues that VUCA calls for a leadership response (George 2017). He therefore adapted the acronym to VUCA 2.0 to underscore the need to have Vision, Understanding, Clarity and Agility to be able to manage a VUCA world (https://www.forbes. com/sites/hbsworkingknowledge/2017/02/17/vuca-2-0-astrategy-for-steady-leadership-in-an-unsteadyworld/\#3ad1567613d8).
What is seen here is the call for novel approaches and creative solutions. For this reason, it is necessary and helpful to understand the process of creativity, which is attended to now.

\section{Creativity as combining available juxtaposed insights}

Participating proactively and not reactively in complex and unpredictable situations calls for creative solutions. There are no blueprints available to follow. For this reason, the creative process needs to be understood.

Creativity has been part of the human condition since time immemorial and forms the basis of innovation and progress that happened through all the ages (Ellis 1986:2-4; Ryhammar \& Brolin 1999:259-266). Thinking about creativity is also as old as civilisation, with the Greeks explaining creativity as being external to the self, and therefore it was about discovering and following rules, whilst the Romans explaining it as internal to the creative person resulting in inspiration and imagination. During the various Renaissance Platonism and Neoplatonism eras as well as the Enlightenment, the source of inspiration was seen as residing inside the creative person.

In modern times, interest focused on issues of personality, how creativity could be tested and measured and how creativity is influenced by genius and intellectual giftedness, and the creative process itself.

Although the understanding of creativity and the teaching of how to be creative benefited from all of this, it is still very difficult to measure it objectively. Recent advances in the neurosciences did shed some new light. Beaty et al. (2018:1087) mentioned that technological and cultural progresses are dependent on the ability of people to generate creative ideas. How those are generated in the brain is, however, not yet properly understood. They used neuroscientific methods such as connectomebased predictive modelling to focus on three neural systems, namely, the default, executive attention and salience networks.

The default network is a set of interacting brain regions that are active when a person is primarily inwardly focused, thinking about the self and others, remembering the past and thinking about the future. It is also involved in the long-term memory consolidation, and it disengages the moment the executive attention network activates.

The executive attention network is about alerting, orienting and executive control. It is regulating thoughts, emotions and responses, and it blocks out distracting or unimportant aspects of the environment and guides the brain to focus on available knowledge and what is really important to attain goals, all the whilst keeping track of progress. 
The salience network monitors and processes both external inputs and internal awareness thereof. Based on what is identified as most salient, relevant functional networks are recruited and activated to manage it.

These three networks usually work in succession, replacing the others when one of them activates. What Beaty and colleagues found was that creative people have the ability to let the networks work simultaneously and in unison. They, therefore, have the ability to bring a thorough and available internal knowledge into play with the awareness of external challenges and to focus on goal-oriented solutions. In this way past, present and future are being brought into play in a generative way.

If $4 \mathrm{IR}$ can be rightfully described as a complex system which cannot be controlled, and if people living in the time of 4IR can participate in this complex system, and if their participation should be creative and not traditional, and if creativity is not about materialising new ideas out of thin air, but are based on a thorough knowledge of the past, a good grasp of the present and a view towards the future, what does Christianity contribute to this complex system? In addressing this question, only a small section of the diverse movement of Christianity will be touched upon, namely some aspects of their biblical tradition, and more specifically some Old Testament stories.

\section{Tradition as contemporary interpretation}

The Bible is seen in Christianity as authoritative and direction-giving in many shades of canonical strictness. In this presentation, the Bible is taken as authoritative in the likes of a life simulator, comparable to a flight simulator. It can be said rather tongue in the cheek that experience is something you get just after you really needed it. In a flight simulator, a pilot-in-training gets the experience beforehand. Pilots master the skills of flying whilst being exposed to all the challenges and possible emergencies they might encounter in ways that do not endanger their own lives and those of real passengers in the plane itself.

Similarly, stories are shared experiences of people, and people listening to or reading them get the opportunity to enter into and participate in the virtual world of the storyteller, engaged but not totally exposed to the real events, challenges and even dangers. Biblical stories are similar to this. They reflect the attempts of people to make sense of their lived realities and everything life throws at them, whether good or bad. In this way, it is not about the historical correctness of what is being told. The historical factualness of the story resides in the creative event that happened in the author's mind and what the author wanted to share and convey by means of the story. It is rarely about how true it is to the events that are referred to in the story, if at all. Similarly, when someone listens to the story, reads it or retells it, it is actually about reliving and participating for the sake of coping with and attributing and finding meaning in their own lived experiences, with the story being a guiding force to these ends.

In these ways, stories in general, and Biblical stories in particular, become facts, events and available knowledge in the lives of people, which they can use when they create sense in and make sense of their lives, and when constructing creative solutions to challenges and new situations (Niederhoffer \& Pennebaker 2002:573-583).

W. Lee Humphreys is a scholar who interprets the Old Testament from this angle. With a focus on narrative and memory, he wrote a book titled 'Crisis and Story: Introduction to the Old Testament' (1990) that captures the dramatic development of the ancient Israelite and early Jewish religious traditions. Humphreys describes two major narrative complexes and three crises in the history of the city of Jerusalem: the Moses-Sinai and David-Zion stories, and David's capture of the city of Jerusalem in the 10th century BCE, Jerusalem's destruction by the Babylonians in 586 BCE and Jerusalem's destruction by the Romans in $70 \mathrm{CE}$. Humphreys considers the complex interplay between religious traditions and political, social, economic, military and cultural factors.

The Moses-Sinai narrative complex tells the story of Israel's deliverance from Egyptian slavery. It is a complex history, but according to Humphreys (1990:13-15) the story can be structured according to three crises in the history of the city of Jerusalem. These crises can be compared to the industrial revolutions of modern times, in the sense that they brought about radical societal, political and economic upheavals and change, which makes it worthwhile to use in this discussion about how to make sense of and participate in the 4IR.

The first crisis was when David captured the older Canaanite city of Jerusalem. In the 11th century BCE, Israel was an insignificant and loose federation of semi-independent tribes in the hill country of lower Palestine. David and his son Solomon changed all these within a single generation by establishing a centralised monarchy and an empire with Jerusalem as capital. They also centralised religion by building a temple in Jerusalem, thereby putting diverse religious beliefs and practices under one umbrella.

This political and religious revolution had a major impact on the lives of ordinary Israelites. Politically they had to get used to being aligned with superpowers in the region such as the Egyptians who were previously seen as their enemy. There was even an Egyptian princess in the court in Jerusalem. Socially and culturally various tribes were brought together as one nation, which previously were enemies fighting over local resources. Religiously the centralised cult of Yahweh had to assimilate into its traditions Canaanite and other previously foreign and even rival religions. The creation of the monarchy brought some advantages in terms of security, trade and 
power but also posed many challenges to the way people lived, worked and believed.

The second crisis ranged from 598 to 587 BCE when Nebuchadnezzar, king of Babylon, captured and destroyed Jerusalem. His forces laid siege to the city for many months, and after untold suffering by the inhabitants, the city walls were breached, the city was captured, and the temple was looted and destroyed. Everything an Israelite took as orientational beacons in life and living was lost. Up until then the Zionist Theology preached that their god Yahweh would protect and bless them, and they took as proofs of that the fact that there was as promised a Davidic king on the throne in Yahweh's chosen city, where his temple was situated, whilst they lived in the promised land.

The fall of Jerusalem and the accompanying events brought about a revolution of immense magnitude in their lives. Apart from the untold suffering they had to endure during the siege, after the fall of the city they had to reorientate politically, having lost their king from the Davidic lineage, who was killed, and the ruling elites were taken to Babylon as exiles. The promised land became a province under Babylonian jurisdiction. The holy city laid in ruins. The temple was looted, desecrated and destroyed, the religious leaders were murdered and basically the cult of Yahweh, as it was until then, came to an end.

This encompassing revolution in their lives and living called for a radical reorientation in every sphere of their lives. Politically Israel came to an end, and henceforth they were known as Jews, not Israelites. Jerusalem was but a memory in ruins. Their religion changed from being templecentred to synagogue-distributed. Their foundational stories had to be transformed and re-storied, and having lost their land, they inhabited the Diaspora, namely wherever they stayed and lived was their land.

The third crisis came about when the province of Judea, once the kingdom of David, came in conflict with the Roman occupiers of their land and city. The revolt took place in the years 66-70 C.E., and in 70 C.E. Jerusalem was again captured and the rebuilt temple was destroyed along with the city. Once again hopes were dashed, and beliefs about politics, society, religion and life in general were questioned. Their foundational stories had to be reinterpreted, and in this time two new streams emerged - one that developed into Judaism and the other that developed into Christianity.

Every one of these three crises brought about wide-ranging changes on every aspect of Israelite and Jewish societies, and the need for people to rethink past, present and future. Attempts to do this can be seen in many but not all of the Biblical stories (Humphreys 1990:15). Other crises in ancient Israel's history, such as domestic struggles, environmental issues and international events, also called for reorientation and adaptation (Smith 2004:46). Bottom line is that crises and revolutions call for people to rethink what they were sure of in the past and where they are headed in the future, all the while trying to figure out what they have to do now to cope with their present situation.

To see what reorientation after a crisis of revolutionary proportions looked like, two Old Testament texts will now be discussed, namely that of Genesis 1 and Lamentations 4 .

\section{Genesis 1}

Traditionally Genesis 1 is often interpreted as describing how the heavens and earth and everything on the earth have been created. The veracity thereof ranged from being taken as that creation took place literarily in 6 days and exactly as has been described, to it being more or less true in the sense that it was six epochs of lengths, to being totally prescientific and untrue. What is shared amongst all these views of Genesis 1 is that all of them take it to be an attempt to describe the process of creation (Bräumer 1983:36; Hoffmeier, Wenham \& Sparks 2015; Westermann 1976:1-11).

Old Testament scholarship for a long time held another view, claiming that in Israel's own view of it was that it was not seen as an attempt to write history of some sort, because it was never mentioned as such in their credo when they mention what they believed were the historical events upon which they based their faith. Von Rad (1972) wrote:

Faith in creation is neither the basis nor the goal of the declarations in Gen., chs. 1 and 2. Rather, the position of both the Yahwist and the Priestly document is basically faith in salvation and election. (p. 46)

If it is not an attempt to describe historical, geological, biological and other events, what is the text about? Old Testament scholarship describes it as a reaction to a historical event, namely the fall of Jerusalem in $586 \mathrm{BCE}$, being one of the three crises Humphreys (1990) refers to. If this is correct, then Genesis 1 is not about creation as such, but about the creation of meaning whilst going through a crisis of worldshattering and revolutionary proportions (Gous 2007:35). In this sense it intended to guide people how to participate in this complex system. As such, it might also inform subsequent hearers and readers how people previously navigated the passage through difficult times, in this sense functioning as 'life simulator training' as mentioned before.

How the author, which incidentally is not seen in Old Testament scholarship as being Moses, made sense of the complex system they all had to manage was that to juxtapose the chaotic complexity as is described in the content with predictability and order in the way it is presented.

The complexity arose as the result of them having lost their previously held orientational beacons, namely their belief that their god Yahweh was the guarantor of their well-being. Up until then, they based their predictable and ordered existence on their belief that He would sustain them by keeping a Davidic king on the throne in Judah, that the city of Jerusalem will be protected as his earthly abode, that the land of Israel will be the sign that he provides the space 
where his people may thrive and that the temple in Jerusalem is the seat of his presence amongst his chosen people.

With the fall of Jerusalem to the Babylonian forces in 586 BCE, the Davidic king was killed, the city was destroyed, the land lost its sovereign status and the temple was destroyed. With all of this, the people of Israel also lost their belief system. Their world changed and therefore their views of how to manage the new world also had to change.

The basic message of Genesis 1 was that there are constants that survive change, and there are expendables that can be let go of because they were proven to be false securities, or they became obsolete, or they were taken away by circumstance.

After the calamitous change brought about by the fall of Jerusalem, many of the leaders were taken into captivity to Babylon. There they encountered Babylonian culture and religion, part of which was the Babylonian creation myth, the Enuma Elish. According to this story, creation took place after a major battle between the mother deity, Tiamat, and her son, Marduk. During this battle, Marduk overcame his mother, killed her and divided her body into two parts, which became the heavens and the earth, respectively. Creation was therefore the result of a battle between gods, and humans had to bring offerings to soothe the gods so that they do not get into battle again, in the process destabilise heavens, earth and societies. The Israelites who were exposed to this entertained the idea that the fall of Jerusalem might have been the result of their god Yahweh being overcome by Marduk, and that they therefore had to accept Marduk as the triumphant god.

The Israelite priests thought differently. They came to realise that all along, they based their faith upon misplaced certainties, and that their God and the accompanying or resultant worldview could survive the calamity if they adapted their views. To communicate these adapted beliefs to the Israelites, they wrote their version of how creation took place, which we find in Genesis 1. The reason they chose to do it in the format of a story about creation was to respond to the competing and concurrent story about creation they encountered in Babylon, which challenged and had a major influence on the minds and beliefs of the people from Jerusalem who was captured and taken there into exile. The Judahite priests, therefore, formulated it in such a way that their audience was led to believe that it is a story similar to the competing Babylonian creation story called the Enuma Elish, using terms in Genesis 1 that reminded the audience of the Enuma Elish and the events related there (Loader 1978:198-204, 2003:313; Waltke 1975:327-342. See also Johnston 2008:194 about Genesis 1 and Egyptian creation myths).

Their counterstrategy was therefore something like the following. Firstly, they made sure about what in their own world view and belief systems stood the test of time in the complex system and changing times they found themselves. Then they identified the aspects that were shown to have become outdated and obsolete, and which needed to be adapted or even discarded. They furthermore participated in the complex system by not closing their eyes to concurrent events and beliefs, but interacting with them, accepting some aspects such as the creation motif, but adapting it to fit into their own adapted belief system.

Their strategy to manage the changes they faced and participate in their complex system was to juxtapose order and renewal. The order was depicted in the progression of 7 days, which was done in a particular way. Days 1-6 were depicted as pairs with logical links between each pair. The first 3 days depicted preparation, whilst days 4-6 depicted completion. On day 1 God created light, and on day 4 the bearers of light. On day 2 water and sky were created, and on day 5 the inhabitants of water and sky, namely fish and birds, were created. On day 3 dry land and plants were created, and on day 6 the inhabitants of land and users of the plants, namely animals and humans, were created. The punchline is to be found in day 7 , which not being part of a pair draws the attention. On that day, henceforth the Sabbath, humans existed whilst being cared for by God and therefore being able to rest, unlike in the Enuma Elish where humans had to take care of the needs of the gods. The message is that even though they contemplated the idea that Yahweh deserted them or that he was conquered, he is still in control and able to care for them, albeit in a new way where the Sabbath is the sign of his care, not the king, land, city or temple (Loader 1978:202; Van Selms 1973:42).

They survived the revolutionary change, with some continuation from before, having discarded obsolete aspects, and creating something new. Their attempt to make sense of disruptive changes can therefore be described as creative participation in a complex system.

\section{Lamentations 4}

The book of Lamentations is a collection of five poems, each poem a reflection on the events surrounding when Jerusalem was conquered in 586 BCE by the Babylonian forces after a nine month siege (Berlin 2002; Dearman 2011; Gerstenberger 2001; Gous 1992; Huey 1993; O'Connor 2003; O'Connor 2015; Salters 1994; Westermann 1990). As such, the poems were attempts to make sense of major changes in all spheres of their lives. Whilst Genesis 1 is more about creating a new worldview to guide people through the new realities, Lamentations is about making sense of the more local and direct experiences which people endured as a result of the events. What is described in these acrostic poems are the naked and brutal realities people experienced. Whilst Genesis 1 is a more abstract reaction to the wide-ranging changes, Lamentations is about concrete events and reflections on it (Reimer 2002:542). On grassroots level, the events disrupted life on the most basic of societal and human levels, bringing about untold suffering and disorientation. Every single sphere of life was turned upside down, from politics, religion, 
societal structures, to physical safety and sustenance. In Lamentations 4 this is taken to an unspeakable level, where the most basic of human societal order is broken, when mothers ate their own children.

In this poem, like in the first three, there is a juxtaposition of form and content. The form is an acrostic poem, meaning each verse starts with a following letter of the Hebrew alphabet. Some commentators see this as a straitjacket stifling the logical flow of thought (Dobbs-Alsopp 1972:20). However, several commentators managed to make sense of the flow of thought, describing it as a spiralling parallelism (Brandscheidt 1983; Gous 1996, 2005; Renkema 1983, 1988):

\section{1-2. Rejection.}

3-4. Distress caused by incompetent mother.

$5-6$. The heavy penalty.

7-8. Chaos.

9-10. Chaos.

11-12. The heavy penalty.

13-14. Distress caused by incompetent leaders.

15-16. Rejection.

17. Futile hope on allies.

18. Foiled by enemy.

19. Foiled by enemy.

20. Futile hope on king.

21. Imminent punishment of Edom.

22. Concluded punishment of Zion.

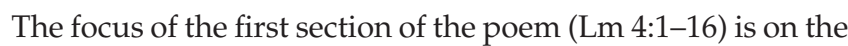
chaos brought about by the events, causing the collapse of all societal structures, the most telling being mothers deserting the most basic of human care and societal structure when they killed and ate their own children.

The second section of the poem ( $\operatorname{Lm~4:17-20)~focuses~on~the~}$ fact that this was the result of them placing their hope on foundations that did not stand the test of time and reality.

The last part of the poem was seen by some commentators as a bit of an embarrassment, in the sense that Israel laments their own suffering, but then in a revengeful manner calls for similar suffering to be brought upon their enemies. In the light of the flow of ideas, it is, however, rather to be seen that there is some kind of predictability and even an inevitable and unavoidable flow of events, being communicated by the verses following the flow of the alphabet, as well as the spiralling parallelism. What they experienced was not an inexplicable and 'out-of-the-blue' chaotic set of events, but the predictable and orderly punishment for their wrongs, which would lead to a similar outcome and punishment for wrongs perpetrated by whoever else also transgressed. Neither revenge nor Schadenfreude is a solution to their problems, and it will also not alleviate any of their own suffering. The utter chaos they experienced was not an unpredictable accident or unintelligible disturbance of their world order; it was the logical outcome because of their transgressions and illogical reliance on unreliable certainties.

These two fossilised memories in Genesis 1 and Lamentations 4, which forms part of the Christian (and Jewish) religious tradition, are available to function as a collective memory and life simulators for adherents to the tradition on how to manage life-changing events in their world and environment.

\section{Change management as intentional participation}

The problem addressed in this article is whether a part of society, namely Christianity, which is seen by some as dated or even outdated, will be able to be involved as a change agent and contribute to and participate in a trailblazing and ground-breaking movement, being the 4IR.

The hypothesis formulated is that contemporary and creative attempts to manage change could benefit from and build upon previous experiences, and therefore collective Christian traditions and institutional memories about managing change are useful and generative for handling contemporary challenges and managing the present-day change.

To understand the current changes in the world brought about by what is called the $4 \mathrm{IR}$, the description from differing points of view of the phenomenon was followed. From one point of view, it is seen as a revolutionary process bringing about wide-ranging changes, mostly positive, and resulting in progress and a better life for all, even though there are possible negative consequences for people as well. From another point of view, it is seen as more of an evolutionary process, with the changes being driven by the few, serving their interests often to the detriment of the many.

Both of these (and other) depictions of 4IR have valid points, and it is not possible or even necessary to choose one over the other. As a matter of fact, the phenomenon of 4IR is so encompassing and wide-ranging that it is impossible and even unhelpful to have a single take on it. For this reason, it is better to describe it as a complex system. As such, the outcomes of the ongoing and pending changes are not possible to plan or even predict. It is a chaotic development, not totally random and incoherent, but constrained by many conditions and realities, developing in a non-linear manner into a new but unpredictable order.

The implication for people in these times of change is that the systems, the movements and the events are too complex to control. One can merely participate. The only question remaining, therefore, is how to participate. To be expected, some participants will have more impact than others. Movers and shakers and drivers of new technological developments will naturally be more impactful than mere users. Captains of industry will drive new developments, and heads of states will influence directions. Ordinary people will also influence and direct, by voting with their 
use of what is available, or organising in labour or social movements. People will support, oppose or ignore.

The collective memory from the Biblical tradition suggests that it is helpful to have some orderly guiding format to assist in making some kind of sense of very confusing situations. In Genesis 1, the 7-day form communicated order in days 1-6 but also renewal in what day 7 brought about. In Lamentations 4, the acrostic (alphabetic form) as well as the spiralling structure helped to communicate that there is some kind of order amongst the experienced chaos, with a renewal of order hinted at towards the end of the poem.

Making sense of the 4IR and the change and even disruptions it brings about might be assisted from some kind of regimen to guide our deliberations. Crises should not be 'solved' too hastily. They should be faced squarely, lived through and used. What I suggest is a game plan that can be summarised in the following three words: Grip, Grapple and Grow. It is a repetitive process with specific content to each of the phases. It is another way of saying that we should come to grips with the difficult phases of life, grapple with them and use it to grow.

\section{Grip: understanding the issues}

Grip is about looking a situation squarely in the eyes. What is needed here is to analyse the situation very deeply, gathering as much information as possible, and seeing it from more than one perspective. What needs to be avoided is a gut-level, knee-jerk reaction based on a limited knowledge base. A person needs to confront the situation and what is happening. Only when a situation is in unblurred sight, although very painful that may be, one can start to grapple with it.

\section{Grapple: reclaiming agency}

To grapple entails struggling with the difficult to deal with situation or series of events. It is during this time that one might feel anger at people who you believe are responsible for what is happening, or when fear about the future without a job or security might drain your resources. It is during this time that you might protest against what you see as an underserved fate. Despite this, people need to understand that blaming, or giving up, or destroying is not constructive. Reclaiming agency and seeing what is within one's personal reach to do are important.

\section{Grow: new lease on life}

To grow is to nurture, shed and renew. Nurturing is to conserve and care for what is healthy and vibrant. Shedding is to leave behind what has died, played its role or became obsolete. Renewing is to replace what has been shed and to add to what is healthy and vibrant. To grow is to move on during or after a crisis on a newly chosen way in the light of the grip that we got on the event and experience, as well as on the basis of how we have grappled to come to an understanding of one's possible agency in it.

\section{Face masks as a case study during turbulent times: Fourth Industrial Revolution, a pandemic and religion}

An example in case is the issue of wearing face masks during the Coronavirus Disease 2019 (COVID-19) pandemic. It is a basic expectation that $4 \mathrm{IR}$ will revolutionise even the most mundane devices we use in everyday life, as has happened when an ordinary talking device (phone) was revolutionised to be a powerful smart device which is everything from a computer to a camera and a window to the world.

The COVID-19 pandemic disrupted the 'normal' flow of events, also of what was expected from progression of matters in 4IR. It posed challenges to current expectations, but also opened opportunities to innovate and come up with creative solutions to problems. For example, Paul Miller, Executive Vice President of Cipla, wrote 'COVID-19 (is) fast-tracking the Fourth Industrial Revolution' (https:// www.cipla.co.za / cipla-news / covid-19-fast-tracking-thefourth-industrial-revolution/; see also Dwolatsky \& Harris 2020; Karr, Loh \& San Andres 2020; Khagram 2020).

One very mundane case in mind is something that literally touches every person on earth today, namely face masks. Face masks have been around for hundreds of years and is mostly very low-tech, being cloth (Nakayama 2020), with some recent developments in density as can be seen in the N95 filtering facepiece, efficiency 2 versions (FFP2), filtering out at least $94 \%$ of airborne particles used by medical professionals (Matuschek et al. 2020). What can be expected in terms of the development of face masks in 4IR spurred by the need for universal adoption and use during and probably after the unexpected crisis brought about by the COVID-19 pandemic? (Matuschek et al. 2020:1-6; Nakayama 2020:557-559).

Starting with the Grip-phase, the pandemic needs to be understood for what it is. The pandemic was an unexpected wildcard during the normal progression and flow of events of the 4IR in 2020, just like the siege of Jerusalem was against the expectations of how life would continue and develop in Judah in the 5th century BCE. In 2020, people expected life to be business as usual, with the normal advancements of technology building upon previous developments. Then the pandemic struck and spread worldwide primarily because of the mobility of people, which is a result of readily available transport. The pandemic led to lockdowns, the closing of businesses and educational facilities, the overwhelming of medical facilities and many deaths. The world grounded to a halt. In a crucible such as this, fault lines become more visible - to be expected, the vulnerable were hit hardest in terms of livelihood, whilst those with access to resources were better off. A few, whose businesses were poised to provide for the needs for people in lockdown and people who were able to continue their work from home, thrived - the likes of Zoom and Amazon and other delivery businesses. 
Focusing on face masks, it is important to Grapple with the issue to decide how to not become a victim of the disease and regain some agency. When it became apparent that face masks might curb the spreading of the virus, the reaction of people to this is a reflection of reactions to all new developments and products. As to be expected, there was a rift between the adopters and the rejectors. The agency the rejectors chose was to oppose the wearing of masks, citing anything from religious beliefs, their rights of freedom to choose, the health hazards of wearing masks, the effectiveness of cloth masks, to questioning the scientific validity of the claims that it might help stop the spreading of the virus (Medina 2020; Pinckard 2020).

Looking forward to a situation where the issue is being managed and the future is being contemplated, it is time to grow, whilst we nurture, shed and renew. Once again, only focusing on wearing masks as a strategy to overcome the challenge, it is also important to see it in the context of the 4IR.

Like in any situation where there is a new need to be met with a product, the adopters ranged from users to entrepreneurs to developers. With a product whose manufacturing is within reach of all people, most people merely started to use what is available on the market. Some started to manufacture it on small scale for personal and family use (Aulicino, Burke \& Lutkoski 2020). The technology available as part of the 4IR made it possible to quickly share ideas how to manufacture the plain masks at home, as can be seen in the many videos that was posted on YouTube and other platforms (CDC 2020). Entrepreneurs saw the potential for large scale sales, and manufacturing started alongside traditional mask suppliers for the medical industry, and those used mainly in the orient as a result of previous viral outbreaks. Cotton masks of all kinds and various levels of sophistication became available. Then businesses in adjacent fields saw opportunities, such as scuba producing companies which traditionally produced swimming and diving masks and started to manufacture face masks (www.scuba.co.za). Specialised masks started to come onto the market, such as for the sports and outdoors market (Olmsted 2020). SEEUS is a company that developed the world's first self-adhering N95 transparent shield and respirator (www.seeus-95.com). From here it was a small step for hi-tech companies to become involved to develop smart masks (https://www.donutrobotics.com/c-mask). Apart from air filtering, which is the basic function of masks, the C-Face Smart Masks connect via Bluetooth to devices, helping people to understand muffled speech more easily, and even sensing face muscles to decipher speech, texting the results to a smartphone. The mask can also record and take minutes of meetings and even do language translation, a handy feature for travellers.

This is the 4IR in action. On the one hand, masks have been around for centuries and have been used in previous pandemics, as well as for a long time in the medical industry. It is hardly a revolutionary, brand-new product. What is new is the development of it in something that exceeds the original use and function, much like the telephone where an ordinary talking device became a multifunction smart tool putting the world in your hand. The smart mask will surely develop into something beyond imagination in years to come, as it is predicted that the current pandemic is far from over, and surely also not the last pandemic humankind will have to contend with.

What should Christians make of this, and does the Christian tradition has anything to say about masks and mask-wearing? On the face of it, absolutely nothing, apart from the question whether one should wear them. Amongst current Christians there are marked differences, with many conservative Christians refusing to wear them - for many reasons, often political as in Bible belt America, or because they believe God will miraculously protect them from the virus. Other Christians do wear them, because in this way they believe they are doing to others what they want to be done to them, and they are protecting themselves and others, especially the vulnerable, from illness and even death (Just 2020:7-12).

The development of the mask is therefore something industrial, a product and technology originally evolutionary to start off years ago, becoming revolutionary with rapid advancement as enabled by recent technologies. The point is however, not so much about the product and the technology, but more about beliefs and values. The pandemic questioned traditional beliefs about the essence of what it means to be human - society, the economy, ethnicity, privilege and everything else. Much of what was taken for granted at the beginning of 2020 was questioned a mere 3 months later. Beliefs about many aspects of human life, also religious beliefs, have been severely shaken. Like in the times of the demise of the Judean way of life in 586 $\mathrm{BCE}$, many current secular and religious beliefs have been found wanting and unreliable, calling them to be shed, and for the formulation of new values and principles for the 'new normal', as in renew. Masks and the wearing of them, whether made of paper or old T-shirts, or being high-tech electronic smart devices, are but one way of deciding upon the values of the new humanity.

This is something we have to come to grips with - looking the new normal squarely in the eye, with an open mind, and analysing carefully what this meant for ourselves and also for people in different situations from us.

Then we have to grapple with the questions posed by the situation and formulate informed and creative solutions.

Only then we will be able to grow beyond where we are now, knowing what is still valid and therefore worthwhile to nurture and keep, what we need to shed because it has become obsolete and what we need to renew and adapt into something that will stand the test of time. 


\section{Conclusion}

The 4IR will bring about many more developments of minor or major implications. How to handle this is based on the values and principles, coming from a particular tradition of which Christianity is but one, but always having to evaluate what to nurture, what to shed and what to renew to be truly human. Experience is usually something we acquire just after we needed it. Opening one up for experience gained by people and who shared that in various ways, like in stories and texts of the kind we encounter in the Christian tradition, may just help us to make sense of changing times.

\section{Acknowledgements Competing interests}

The author declares that he has no financial or personal relationships that may have inappropriately influenced him in writing this article.

\section{Author's contribution}

I.G.P.G. is the sole author of this research article.

\section{Ethical considerations}

This article followed all ethical standards for research without direct contact with human or animal subjects.

\section{Funding information}

This research received no specific grant from any funding agency in the public, commercial or not-for-profit sectors.

\section{Data availability}

Data sharing is not applicable to this article as no new data were created or analysed in this study.

\section{Disclaimer}

The views and opinions expressed in this article are those of the author and do not necessarily reflect the official policy or position of any affiliated agency of the author.

\section{References}

Aulicino, B., Burke, K.L. \& Lutkoski, S., 2020, 'Making a medical face mask at home', American Scientist, viewed 25 June 2020 , from https://www.americanscientist. $\mathrm{org} / \mathrm{blog} /$ from-the-staff/making-a-medical-face-mask-at-home.

Beaty, R.E., Kenett, Y.N., Christensen, A.P., Rosenberg, M.D., Benedek, M., Chen Q. et al., 2018, 'Robust prediction of individual creative ability from brain functional connectivity', Proceedings of the National Academy of Sciences 115(5), 1087-1092. https://doi.org/10.1073/pnas.1713532115

Bennis, W. \& Nanus, B., 1985, Leaders: Strategies for taking charge, Harper Collins, New York, NY.

Berlin, A., 2002, Lamentations (2002): A commentary, John Knox, Westminster.

Brandscheidt, R., 1983, Gotteszorn und Menschenleid:Die Gerichtsklage des leidenden Gerechten in Klgl 3, Trierer Theologische Studien; Bd. 41, Paulinus-Verlag, Trier.

Bräumer, H., 1983, Das erste Buch Mose: 1. Teil, Kapitel 1 bis 11, Wuppertale Studienbibel, Brockhaus Verlag, Wuppertal.

Centers for Disease Control and Prevention (CDC), 2020, How to make masks: CDC on homemade masks, viewed 25 April 2020, from https://www.cdc.gov/ coronavirus/2019-ncov/prevent-getting-sick/how-to-make-cloth-face-covering. html.
Cropanzano, R., 2009, 'Writing nonempirical articles for journal of management: General thoughts and suggestions', Journal of Management 35(6), 1304-1311. https://doi.org/10.1177/0149206309344118

Dearman, J.A., 2011, Jeremiah, Lamentations, Zondervan Academic, Grand Rapids, MI.

Dobbs-Allsopp, F.W., 1972, Lamentations, vol. 7, Westminster John Knox Press, Louisville, TX.

Dwolatsky, B. \& Harris, M., 2020, 'The world is flat: Covid-19 becomes the driving force for $4 \mathrm{R}^{\prime}$, Daily Maverick, viewed 16 April 2020, from https://www.dailymaverick.co.za/ article/2020-06-01-the-world-is-flat-covid-19-becomes-the-driving-force-for-4ir/.

Ellis, A.S., 1986, 'An historical overview of creativity with implications for education', MA thesis, Department of Education, Portland State University.

George, B., 2017, 'VUCA 2.0: A Strategy For Steady Leadership In An Unsteady World', Forbes, viewed 30 April 2020, https://www.forbes.com/sites/hbsworkingknowledge/ 2017/02/17/vuca-2-0-a-strategy-for-steady-leadership-in-an-unsteadyworld/\#3ad1567613d8.

Gerstenberger, E., 2001, Psalms, part 2, and Lamentations, William B. Eerdmans, Grand Rapids, MI.

Gilson, L.L. \& Goldberg, C.B., 2015, 'Editors' comment: So, what is a conceptual paper?', Group and Organization Management 40(2), 127-130. https://doi: paper?, Group and Organizat

Gous, I.G.P., 1992, 'A survey of research on the book of Lamentations', Old Testament Essays 5(2), 184-205.

Gous, I.G.P., 1996, 'Mind over matter: Lamentations 4 in the light of the cognitive sciences', Scandinavian Journal of the Old Testament 10(1), 69-87. https://doi. org/10.1080/09018329608585083

Gous, I.G.P., 2005, 'Lamentations 4 in the light of Poetry therapy', Old Testament Essays 18(2), 223-239.

Gous, I.G.P., 2007, 'Meaning-intelligently designed: Keeping the Bible in (a modern) mind', Old Testament Essays 20(1), 34-52.

Hoffmeier, J.K., Wenham, G.J. \& Sparks, K.L., 2015, Genesis: History, fiction, or neither?: Three views on the Bible's earliest chapters, Zondervan, Grand Rapids, MI.

Huey, F.J., 1993, Jeremiah, Lamentations: An exegetical and theological exposition of holy scripture, vol. 16, Broadmans Press, Nashville, TN.

Humphreys, W L,1990, Crisis and story: An introduction to the old testament, Mayfield Publishing Company, Mountain View, CA.

Innes, J.E. \& Booher, D.E., 2018, Planning with complexity: An introduction to collaborative rationality for public policy, Routledge, New York, NY.

Johnston, G.H., 2008, 'Genesis 1 and ancient Egyptian creation myths', Biblioteca Sacra 165(168), 178-194.

Just, B., 2020, 'Historic plagues and Christian responses: Lessons for the church today?', Christian Journal for Global Health 7(1), 7-12.

Karr, J., Loh, K. \& San Andres, E., 2020, COVID-19, 4IR and the future of work, APEC Policy Support Unit Policy Brief no. 34, viewed 23 April 2020, from https://www. apec.org/Publications/2020/06/COVID-19-4IR-and-the-Future-of-Work.

Kauffman, S.A. 1993, The origins of order: Self-organization and selection in evolution, Oxford University Press, Oxford.

Khagram, S., 2020, 'How the coronavirus pandemic accelerates the 4th Industrial Revolution', The Economist, viewed 24 April 2020, from https://www.newswise. com/coronavirus/how-coronavirus-pandemic-accelerates-the-technology-of-the4th-industrial-revolution-https-eiuperspectives-economist-comfinancialsth-industrial-revolution-https-eiuperspectives-economist-comfinancialserviceswhy-coronavirticle_id=730580.

Loader, J.A., 1978, 'Onqelos Genesis 1 and the structure of the Hebrew text', Journal forthe Study of Judaism 9(1), 198-204. https://doi.org/10.1163/157006378x00265

Loader, J.A., 2003, 'The primeval narrative', OTE 16/2, 309-321.

MacIntosh, R. \& MacLean, D., 1999, 'Conditioned emergence: A dissipative structures approach to transformation', Strategic Management Journal 20(4), 297-316. https://doi.org/10.1002/(SICI)1097-0266(199904)20:4\%3C297::AIDSMJ25\%3E3.0.CO;2-O

MacIntosh, R. \& MacLean, D., 2001, 'Conditioned emergence: Researching change and changing research', International Journal of Operations and Production Management 21(10), 1343-1357. https://doi.org/10.1108/EUM0000000005973

MacIntosh, R. \& MacLean, D., 2015, 'Complexity theory', in N. Beech \& C. Gilmore (eds.), Organising Music: Theory, practice, performance, pp. 152-161, Cambridge University Press, Cambridge.

MacIntosh, R., MacLean, D., Stacey, R. \& Griffin, D. (eds.), 2006, Health complexity and organization: Readings and conversations, Routledge, London.

MacLean, D. \& MacIntosh, R., 2003, 'Complex adaptive social systems: Towards a theory for practice', in E. Mitleton-Kelly (ed.), Complex systems and evolutionary perspectives on organizations: the application of complexity theory to organizations, pp. 149-65, Elsevier Science BV, Amsterdam.

Matuschek, C., Moll, F., Fangerau, H., Fischer, J.C., Zänker, K., Van Griensven, et al., 2020 , 'The history and value of face masks', European Journal of Medical Research 25(1), 1-6. https://doi.org/10.1186/s40001-020-00423-4

Medina, A., 2020, 'Why are people refusing to wear masks amid coronavirus threat?', viewed 22 April 2020, from https://www.ksat.com/news/local/2020/05/27/whyare-people-refusing-to-wear-masks-amid-coronavirus-threat/.

Miller, P., 2020, 'COVID-10 fast-tracking the Fourth Industrial Revolution', viewed 22 April 2020, from https://www.cipla.co.za/cipla-news/covid-19-fast-tracking-thefourth-industrial-revolution/. 
Nakayama, D.K., 2020, 'Surgical masks during the Influenza Pandemic of 1918-1920', The American Surgeon 86(6), 557-559. https://doi.org/10.1177/0003134820933216

Niederhoffer, K.G. \& Pennebaker, J.W., 2002, 'Sharing one's story: On the benefits of writing or talking about emotional experience', in C.R. Snyder \& S.J. Lopez (eds.) Handbook of positive psychology, pp. 573-583, Oxford University Press, New York, NY.

Northrop, R.B., 2010, Introduction to complexity and complex systems, CRC Press, London.

O'Connor, K.H., 2015, Lamentations and the tears of the world, Orbis Books, Maryknoll, NY.

O'Connor, K.M., 2003, 'Lamentations', Interpretation 57(1), 80. https://doi. org/10.1177/002096430005700115

Oliver, E., 2019, 'The great emergence: An exposition', HTS Teologiese Studies/ Theological Studies 75(4), 1-12. https://doi.org/10.4102/hts.v75i4.5398

Olmsted, L., 2020, 'The best face masks for you from top outdoor gear specialists', Forbes, viewed 01 August 2020, from https://www.forbes.com/sites/ larryolmsted/2020/08/01/the-best-face-masks-for-you-from-top-outdoor-gearspecialists/amp/.

Peat, D. \& Briggs, J., 1999, Seven life lessons of chaos, Harper Collins, New York, NY.

Pinckard, C., 2020, 'Ohio legislator cites God for refusing to wear face mask during coronavirus crisis', viewed 24 April 2020, from https://www.cleveland.com/ coronavirus/2020/05/ohio-legislator-cites-god-for-refusing-to-wear-face-maskduring-coronavirus-crisis.html.

Prisecaru, P., 2016, 'Challenges of the Fourth Industrial Revolution' Knowledge Horizons - Economics 8(1), 57-62.

Reimer, D.J., 2002, 'Good grief? A psychological reading of Lamentations', Zeitschrift für die alttestamentliche Wissenschaft 114(4), 542-559. https://doi.org/10.1515/ zatw.2002.030

Renkema, J., 1983, Misschien is er hoop: De theologische vooronderstellingen van het boek Klaagliederen, T. Wever B.V, Franeker.

Renkema, J., 1998, Lamentations, Peeters, Leuven.

Ryhammar, L. \& Brolin, C., 1999, 'Creativity research: Historical considerations and main lines of development', Scandinavian Journal of Educational Research 43(3), 259-273, https://doi.org/10.1080/0031383990430303
Salters, R.B., 1994, Jonah and Lamentations, JSOT, Sheffield.

Schwab, K., 2015, 'The Fourth Industrial Revolution: What it means and how to respond', viewed 28 April 2020, from https://www.foreignaffairs.com/ articles/2015-12-12/fourth-industrial-revolution; https://947.co.za/articles/2020/ 05/06/world-economic-forum-the-fourth-industrial-revolution-what-it-means-howto-respond.

Schwab, K., 2016, The Fourth Industrial Revolution, World Economic Forum, Geneve.

Smith, M.S., 2004, The memoirs of God. History, memory, and the experience of the divine in Ancient Israel, Fortress Press, Minneapolis, MN.

Unwin, T., 2019, 'Why the notion of a Fourth Industrial Revolution is so problematic', Wordpress, viewed 28 April 2020, from https://unwin.wordpress com/2019/03/09/why-the-notion-of-a-fourth-industrial-revolution-is-soproblematic/.

Van Selms, A., 1973, Genesis deel 1, Callenbach, Nijkerk.

Von Rad, G., 1972, Genesis, SCM Press, London.

Wahl, D.C., 2017, 'Understanding complexity: A prerequisite for sustainable design', Medium, viewed 27 April 2020, from https://medium.com/age-ofawareness/understanding-complexity-a-prerequisite-for-sustainable-designfd45990e3bd6.

Wahl, D.C., 2019, 'A brief history of systems science, chaos and complexity', Resilience, viewed 27 April 2020, from https://www.resilience.org/stories/2019-09-12/ a-briefhistory-of-systems-science-chaos-and-complexity/.

Waltke, B.K., 1975, 'The creation account in Genesis 1:1-3', Biblioteca Sacra 132, 327-342.

Westermann, C., 1976, Genesis 1-11, Wissenschaftliche Buchgesellschaft, Erträge der Forschung, Band 7, Wissenschaftliche Buchgesellschaft, Darmstadt.

Westermann, C., 1990, Die Klagelieder, Forschungsgeschichte und Auslegung, Neukirchener, Neukirchen-Vluyn

Xu, M., David, J.M. \& Kim, S.H., 2018, 'The fourth industrial revolution: Opportunities and challenges', International Journal of Financial Research 9(2), 90. https:// doi:10.5430/ijfr.v9n2p90 